\title{
КУЛЬТУРНАЯ ЗНАЧИМОСТЬ СЛОВА ВОЛК \\ ПО МАТЕРИАЛАМ ФРАЗЕОЛОГИИ (ДИАХРОНИЧЕСКИЙ АСПЕКТ)
}

\author{
А. В. Алексеев \\ Московский городской педагогический университет
}

\author{
THE CULTURAL VALUE OF THE WORD VOLK (WOLF) BASED \\ ON THE MATERIALS OF PHRASEOLOGY (DIACHRONIC ASPECT)
}

\author{
A. V. Alekseev \\ Moscow City Pedagogical University
}

\begin{abstract}
Аннотация: предмет статьи - устойчивые выражения номинативного и коммуникативного типов, включаюшие опорное слово «волк». Рассматриваются символические значения слова «волк», реализуемые во фразеологизмах, составляющих семантическое поле более чем из 370 единиц. Цель работь - описать культурную значимость слова «волк», образуемую символическими значениями (символическими признаками) слова. Культурная значимость слова рассматривается в диахроническом аспекте: от ее архаического состояния в праславянский период к семантике древнерусского времени, с учетом оценочной модификации после принятия христианства и последующей трансляции традиционных признаков в современном русском языке. В работе применяется сравнительно-исторический метод, позволивший реконструировать древнерусскую пословииу ( *про вълка гълка, а вълкъ из колъка) и архаччное символическое значение слова волк - 'злой пастух'. Это значение опирается на мифологические представления праславянской эпохи: анализ пословии показывает, что волк воспринимался как воплощение языческого божества плодородия Яриль, сохраняющего скот и принимающего жертвы. Полученные выводы опираются на структурно-семантический метод, в соответствии с которым культурная значимость слова «волк» складывается из совокупности семантических признаков, полученных при анализе отдельных языковых единиц четырех секторов ('овцы', 'одушевленный объект', 'ситуация взаимодействия с волками', 'стереотипные качества') фразеологического семантического поля. В результате анализа был определен символический образ волка: неизменный и бескомпромиссный противник человека, опасный обитатель чужсог, потустороннего мира, способный вторгаться в обыденный мир, жестокий и решительный хищник, чей характер определен самим мироустройством. Полученные результаты актуальны для исторической лексикологии и лингвокультурологии и могут быть использованы при составлении исторического словаря символических значений. Проведенным анализом установлено, что происхождение символических значений слова «волк» связано с мифологическими представлениями аграрного общества, с древним содержанием русского народного праздника Юрьев день (весенний).
\end{abstract}

Ключевые слова: историческая лексикология, культурная значимость, символическое значение, фразеология, паремии, синхрония и диахрония.

\begin{abstract}
: the research object of the article is stable expressions of nominative and communicative types, including the reference word volk (wolf). The article considers symbolic value of the word volk (wolf), realized in phraseological units that make up a semantic field of more than 370 units. The aim of the work is to describe the cultural value of the word volk (wolf), formed by the symbolic meanings (symbolic signs) of the word. The cultural value of the word is considered in a diachronic aspect: from its archaic state in the pre-Slavic period to the semantics of the old Russian time, taking into account the estimated modification after the adoption of Christianity and the subsequent translation of traditional features in the modern Russian language. The work uses a compar-
\end{abstract}

(C) Алексеев А. В., 2020

Контент доступен под лицензией Creative Commons Attribution 4.0 License. The content is available under Creative Commons Attribution 4.0 License. 
ative-historical method, which allowed to reconstruct the oldest old Russian proverb (*pro volka golka, a volk iz kolka) and the archaic symbolic meaning of the word volk (wolf) - 'evil shepherd'. This meaning is based on the mythological representations of the pre-Slavic era: the analysis of proverbs shows that the wolf was perceived as the embodiment of the pagan fertility deity Yarila, preserving cattle and accepting sacrifices. The findings are based on the structural-semantic method, according to which the cultural value of the word volk (wolf) consists of a set of semantic features obtained in the analysis of individual language units of the four sectors ('sheep', 'living object', 'situation of interaction with wolves', 'stereotypical qualities') of the phraseological semantic field. As a result of the analysis, the symbolic image of the wolf was described: the unchanging and uncompromising enemy of man, a dangerous inhabitant of another, supernatural world, able to invade the everyday world, cruel and strong predator, whose character is determined by the world order. The results obtained are relevant for historical lexicology and linguoculturology and can be used in compiling a historical dictionary of symbolic meanings. The analysis established that the origin of the symbolic meanings of the word volk (wolf) is associated with mythological representations of agricultural society, with the ancient content of the Russian folk holiday Yuriev day (spring).

Key words: historical lexicology, cultural value, symbolic meaning, phraseology, paremia, synchrony and diachrony.

Под культурной значимостью слова понимаются такие семантические признаки, которые формируются при взаимодействии семиотических систем языка (лексики) и культуры: «значимость лексического знака определяется не только его отношениями с другими словами, но и всеми отношениями в системе культурных знаков» [1, с. 71]. Культурная значимость образуется суммой символических значений слова, узуальных и окказиональных, которые реализуются в определенных речевых условиях и выявляются путем контекстуального анализа. Символическое значение слова возникает в результате взаимодействия непосредственного лексического значения и культурных ценностей, культурных смыслов, причем лексическое значение оказывается означающим символа, а культурная ценность - его означаемым. Понятие культурной значимости слова сближается с понятием культурной коннотации, поскольку под последней понимается «интерпретация денотативного или образно мотивированного, квазиденотативного, аспектов значения в категориях культуры» [2, с. 214]. Символические значения слова обычно реализуются в жанрах высокого стиля, в религиозном дискурсе, в прецедентных текстах. При описании идиом, т. е. фразеологизмов в узком смысле, символическое значение выявляется путем сопоставления буквального и обобщенно-переносного значения фразеологизма. При описании паремий, т. е. коммуникативных фразеологических единиц, символические значения и в целом культурную значимость опорных слов возможно исследовать путем контекстуального анализа. Сложность описания культурной значимости слов и фразеологизмов связана с тем, что составляющие ее семантические признаки не очевидны и исторически изменчивы. Такие признаки обычно не указываются лексикографическими источниками и не всегда осознаются говорящими, для их выявления необходим особый диахронический анализ. Диахроническое описание культурной значимости слова и включающих его фразеологизмов проводится ниже на материале лексемы волк.

По данным фразеологических словарей, в современном русском языке существуют следующие фразеологизмы с компонентом волк (даются здесь в основной форме без учета варьирования): волк в овечьей шкуре (1), морской волк (2), травленыий волк (3), волком выть (4) в словаре под редакцией А. И. Молоткова [3, с. 76]; в словаре под редакцией А. Н. Тихонова [4, с. 162] те же, а также волком смотреть (5), голодный как волк (6), хоть волком вой (7). Из этого списка $\Phi 1$ является по происхождению церковнославянизмом [5, с. 94]. В этимологическом фразеологическом словаре также отмечается исконно русское происхождение $Ф 7$ (очевидно, то же относится и к Ф4), а также указаны еще два фразеологизма: пора меж волка и собаки (8) - поздняя калька из французского языка [5, с. 95]; пожалел волк кобылу (9). Последний из указанных фразеологизмов является поговоркой и происходит из пословицы (ср. пожалел волк кобылу, оставил хвост да гриву [6, с. 257]), что свидетельствует о его исконно русском характере. Фразеологизм морской волк стал употребляться в значении 'опытный моряк', по данным НКРЯ, в середине XIX в.: Путешествия его - ряд приключений [...] Это настоящий морской волк. Гончаров. 1855 г. [7]. В XVIII в. это словосочетание использовалось не в качестве идиомы, а в качестве фразеологического сочетания терминологического характера (в ряду других названий животных): Въ семъ заливъ найдено было великое множество такъ названныхъ морскихъ волковъ, звърей лютыхъ... Веревкин. 1782 г. [7].

Среди рассмотренных выше фразеологизмов, зафиксированных в специальных словарях, два оказываются заимствованными и о культурной значимости русского слова, казалось бы, свидетельствовать не могут. Однако культурная значимость (символи- 
ческое значение) Ф2 морской волк тождественна культурной значимости (символическому значению) Ф3 травленый волк - 'опытность' (по другим источникам также старый (стреляный) волк). Образ травленого, преследуемого волка, в свою очередь, является исконным для русской культуры: об этом свидетельствуют многочисленные пословицы (см. ниже). Фразеологизм Ф1 является не обычным заимствованием, но библеизмом, безусловно, прецедентным для русской культуры. Исконный характер оставшихся фразеологизмов подтверждается анализом пословиц и славянского материала. Поскольку в истории русского языка наблюдается подвижность границ между идиомами и паремиями, культурную значимость и культурную коннотацию фразеологизмов различных типов необходимо рассматривать в рамках единого описания.

Русских паремий с компонентом волк зафиксировано в различных источниках на порядок больше, нежели фразеологизмов в узком смысле. В классическом источнике - словаре В. И. Даля приведено 69 пословиц со словом волкъ [8, с. 205-206]. В сборнике В. И. Даля «Пословицы русского народа» (издан в 1862 г.) 219 соответствующих фразеологических единиц. В источнике начала ХХ в. [9], составленном в том числе на литературном материале и не различающем идиомы и паремии, - 68 фразеологических единиц. В словаре поговорок 2007 г., включающем среди прочего и современные жаргонные примеры, 44 образных выражения. Наконец, в наиболее обширном сборнике, представляющем собой компиляцию различных источников (2009 г.), 332 фразеологические единицы с компонентом волк (включая варианты).

Интегральный список фразеологических единиц с компонентом волк, составленный нами по нескольким источникам XVII-XXI вв., составил, после отождествления синхронных и исторических вариантов, 378 пунктов. Для вычленения когнитивного содержания (культурных значимостей, коннотаций) эти фразеологизмы должны быть рассмотрены как семантическое поле, имеющее ядро, центр и периферию. Структура поля разграничивается нами в соответствии со степенью прецедентности фразеологических единиц, определяемой их распространенностью. Фразеологические единицы, отмеченные более чем в половине рассмотренных источников, относим к ядру семантического поля. Однократно употребленные фразеологизмы составляют его периферию; промежуточная степень фиксации определяет принадлежность фразеологической единицы к центру семантического поля.

В тематическом отношении семантическое поле можно разделить на четыре сектора: 1) фразеологизмы, содержащие указание на овцу, стадо, пастуха, -80 фразеологических единиц; 2) фразеологизмы, в которых «контрагентом» волка выступает какой-либо иной одушевленный объект (обычно животное), помимо овцы или пастуха, - 108 фразеологических единиц; 3) фразеологизмы, образной основой которых оказывается какая-либо ситуация взаимодействия с волками; сюда же мы относим проекцию отношений с волком на отношения с какими-либо социальными группами - 94 фразеологические единицы; 4) фразеологизмы, образной основой которых являются те или иные общепризнанные, стереотипные качества волка, - 96 фразеологических единиц.

В рассмотренном семантическом поле древнейшим фразеологизмом письменного происхождения является волк в овечьей шкуре, на первый взгляд несомненный библеизм: иже приходнть къ вамъ. въ одеждахъ овьчахъ. жтрьдоу же сжть вълии. Остромирово евангелие. 231. Мф 7:15. О раннем вхождении фразеологизма в русский узус свидетельствует цитата из сочинения Кирилла Туровского: Арии... съсоудъ бг сотонинъ и волкъ, швчею покровенъ кожею. КТур XII сп. XIV, 58 [10, с. 160]; аналогичный пример отмечен в тексте XVIII в.: ...оберегай от волков кожами овчими одъянных. Пркп. 38 [11, с. 38]. Ср. другие варианты фразеологизма в продолжение ряда одежды / кожа: знать волка и въ овечьей шкург [8, с. 205]; ...в овечьей шубе [9], ...в овчине [6, с. 396]. Варианты кожа (др.-рус. 'шкура') и шкура усиливают означающее символа, т. е. образ, лежащий в основе переноca. Между тем церковнославянский вариант одежда точнее соответствует греческому оригиналу, где используется हैं $\delta v \mu \alpha$ 'одежда, платье', за счет чего усиливается означаемое символа, т. е. указание на моральное качество человека, 'коварство'. Усиление образа (означающего символа) является не только русской, но общеславянской особенностью, ср. польск.: wilk w owczej skórze [12, с. 137]. Кроме того, употребление лексемы шкура коррелирует с русским семантическим полем исследуемых фразеологизмов: в его периферии присутствует целый ряд фразеологизмов с этим словом: волка не испугаешь овечьей шкурой; волк меняет шкуру, а не душу; волк бережет свою шкуру, а человек-имя. Указанные факты позволяют учитывать славянское происхождение образа, лежащего в основе фразеологизма волк в овечьей uкуре.

Можно предположить, что культурная значимость волк 'коварство, обман' является универсалией всего европейского культурного пространства. Оппозиция волка и овцы широко использовалась в качестве образной основы культурной коннотации (символа) как в христианской письменной культуре, так и в славянской народной культуре. Ср. еще один церковнославянский пример: се азъ сълу вы яко швьия посргдљ вълкъ. Мф 10:16. Тип. ев. 19 [13]; в данном контексте 
реализуется культурная значимость волк 'злой, жестокий' (ср. далее в евангельском тексте в Синодальном переводе: Остерегайтесь же людей: ибо они будут отдавать вас в судилища и [...] будут бить вас. Мф 10:16). Аналогичные противопоставления неоднократно встречаются в древнерусских текстах, ср. летописный пример, отсылающий читателя к церковнославянскому выражению в Мф 7:15: Aщзе хто хулить словъньскую грамоту да будеть белученъ $\bar{w}$ ирквве... ти бо суть волц̧и а не жвц̧а. Лаврентьевская летопись, 9об. Вместе с тем в летописном фрагменте, посвященном конфликту древлян с киевским князем Игорем, в примере, содержащем образец восточнославянской разговорной речи того времени, присутствует древнерусская пословица, не сохранившаяся до нашего времени: Аще сл въвадить волкъ в ови̧г. то вълносить все стадо. Лаврентьевская летопись, 14об. Сопоставление приведенных летописных примеров позволяет утверждать, что противопоставление «волк - овцы» было древнерусским архетипом и книжной, и народной культуры.

Ядро современного сектора 'овцы' фразеологического семантического поля 'волк' составляют следующие пословицы: 1) выть тебе волком за свою овечью nростоту (культурная значимость волк 'страдание'); 2) ловит (крадет) волк (волчок) (и) роковую (считанную, меченую) овиу (культурная значимость волк 'неизбежность зла'); 3 ) волк в овечьей шкуре (культурная значимость волк 'коварство'); 4) не за то волка бьют, что сер, а за то, что (овиу) съел (культурная значимость волк 'реальная вина'); 5) и такое былает, что овца волка съедает (культурная значимость волк 'обычно хищник'); 6) и волки cыmbl, и овцзы цуель (с возможностью метатезы компонентов; культурная значимость волк 'хищник как элемент равновесия'). Последний фразеологизм, несомненно, относится к праславянскому фразеологическому фонду (с учетом исторического варьирования), ср. укр. $i$ вовки ситi, $i$ кози иүілі, серб. и вук сит, и овце (козе) на броју [14, c. 63]; польск. $i$ wilk syty, i owca cała [12, c. 137]. Еще 21 фразеологизм относится к центру первого сектора. Из них наиболее близок к ядру фразеологизм поставить волка в пастухи, широко представленный в вариантах и парафразах: волка въ пастухи поставили; худо овиам, где волк в пастухах; добръ волкъ до овеиъ да пасти ему не дадутъ; серб. поставити вука за пастиря (во всех случаях культурная значимость волк 'губит, а не спасает'). Итак, образная основа «волк овцы - пастух» характерна для большого числа русских и славянских фразеологизмов. Эта образность (означающее символа) сложилась уже в общеславянский период; при переводе библейских текстов уточнялось означаемое символических значений.

К ядру второго сектора семантического поля относятся следующие фразеологизмы: 1) от волка ушел (бежал), на медведя напал (попал), ср. польск. исhоdzac przed wilkiem, trafit na niedźwiedzia (культурная значимость волк 'существо менее опасное, чем эталон опасности'); 2) лезет (не суйся, куда соваться) в волки, а хвост собачий (а хвост телкин, с телячьим хвостом) (культурная значимость волк 'смелый (сильный) по-настоящему, а не притворно'); 3) дай Бог нашему теляти (теленку) волка поймати (лягати, съесть) (культурная значимость волк 'всегда хищник, а не жертва'); 4) ни (то) волк, ни (то) пес (собака) (культурная значимость волк 'определенное зло, несомненный враг человека'); 5) (кто) родился волком, лисицей не бывать (культурная значимость волк 'предопределенность, неизменность характера'). К центру семантического поля могут быть отнесены 52 фразеологические единицы, в которых волк оказывается объектом самых различных противопоставлений, чаще всего волкъ - теля (теленок) и волксобака (ср. выше). Собаке (псу) волк противопоставляется по признакам 'невозможность приручить', 'вечная вражда (с собакой, т. е. с установленным общественным порядком)'. Также «контрагентами» волка в пословицах регулярно выступают лиса, медведь, коза (козел), кобыла (конь, жеребец). На их фоне волк - самый смелый (но не самый хитрый и сильный) хищник, с которым нельзя вступать ни в какие переговоры.

Ядро третьего сектора семантического поля составляют следующие фразеологизмы: 1) на волка помолвка (культурная значимость волк 'в общественном мнении виноват в любом преступлении'); 2) волк легок на помине (культурная значимость волк 'всегда рядом, потусторонняя, нечистая сила'; второй компонент выявляется типологически, в системе культурных знаков: во многих культурах чертей запрещено упоминать, ср. ниже чередование волк/черт); 3) maскал волк, потащили и волка (ловит - ловят / носилпонесли / гоняет - погонят), ср. польск. nosit wilk, ponieśli $i$ wilka (культурная значимость волк 'наказание неизбежно'); 4) сказаль бы словечко, да волкъ недалечко (культурная значимость волк 'постоянный враг'); 5) как волка ни корми (ласкай), он все в лес глядит (смотрит, помнит, норовит), ср. в XVII в.: колко волка ни кормить а онъ кльсу глядить, польск. natura wilka ciagnie do lasu (культурная значимость волк 'лес (дебри, дикая территория) - родное место'); 6) с волками жить, по-волчьи выть (либо с волками жить, либо съеденному быть) (культурная значимость волк 'сила коллектива, обязательность (плохого) поведения'); 7) волков бояться, в лес не ходить (не иметь грибков, ягод), ср. в XVII в.: боятся волковъ быть без грибковъ (культурная значимость волк 'опасен, хозяин (леса)'); 8) счастье - что волк: обманет (да) в лес уйдет (культурная значимость волк 'коварство, непостоянство'). В центр третьего секто- 
ра семантического поля входят еще 20 фразеологических единиц; в этих пословицах широко представлены словоформы, рифмующиеся с формами слова волк: гонку, колку, голку, холку, колка, голка. Активное использование этого художественного приема свидетельствует об актуальности для народной поэзии образа хищного опасного зверя, причем во многих случаях реализуется культурная значимость волк 'объект охоты, преследования человеком', ср.: веселье волку, какъ не сльишть за собою гонку (голку, гоняютъ по колку). Образ волка сохраняет свою актуальность в фольклоре и просторечной речи и в XXXXI вв.: тебе товарищ тамбовский / брянский волк (выражение, связанное с отношениями заключенных и вольнонаемных [15, с. 96]); в изданиях последнего времени приведены и совсем новые пословицы, сохраняющие традиционную культурную коннотацию: в сборнике Н. В. Уварова восемь пословиц, в которых волк соотносится с фашистом, вредителем или лодырем, ср.: достанется фашистскому волку на холку $[16$, с. 99]; в недавнем словаре поговорок приведены современные жаргонные фразеологизмы $[15$, с. $96-$ 97].

Универсальность европейского образа волка затрудняет разграничение типологических связей, генеалогической общности и заимствования. Сp. рус. вызваль волка изъ колка (колок - 'маленький лес') и польск. wywołać wilka z lasu (культурная значимость волк / wilk 'опасность, которой нужно всегда остерегаться'). Приведенные пословицы могут восходить к одной форме, развившейся в результате лексического варьирования. С другой стороны, само варьирование может быть результатом взаимодействия различных лексических областей, в том числе при заимствовании, ср. выше волк в овечьей одежде (церк.-сл. одежда) / волк в овечьей шкуре (разг. шкура). Ср. пословицу ловит (крадет) волк (волчок) (и) роковую (считанную, меченую) овиу. Старая русская пословица (ср. в XVII в.: ловить волчокь роковую овечку [17, c. 117]) имеет латинскую параллель: lupus non veretur etiam numeratas oves devorare [18, с. 137]. Возможно, и это варьирование, и варьирование колок / las возникло в результате независимого осмысления близких (тождественных) образов. Достаточно неопределенным оказывается происхождение фразеологизмов на волка помолвка и волк легок на помине. В первом случае источником может являться басня Эзопа, в которой представлена та же ситуация, что восстанавливается при этимологизации поговорки на волка помолвка. Ср. полный вид исходной пословицы: на волка помолвка, а (пастухи шалять / пастух (цььган, татарин) теленка (кобылу) украл (съел). Тот же мотив встречается в различных переложениях в баснях И. А. Крылова: на волка только слава, А ест овецто-Савва. Пастух; Волк ... видя, ... Что ... Спокой- но Пастухи барашка потрошат ... Сам молвил про себя...: «Какой бы шум вы все здесь подняли, друзья, Когда бы это сделал я!» Волк и пастухи. Тот же античный сюжет был известен и в Древней Руси, ср.: Волкъ, видъвъ пастуха, ьдущча чюжи овции отай въ кучг, и рече: «О, колико бысте голкы съставили, оже быхъ то я створиль!» Пчела, сп. XIV в. Близкий по лексическому составу к древнерусскому тексту вариант пословицы зафиксирован в сборнике XVII в.: огласила волка мирская голка [17, с. 130]. Итак, с одной стороны, наблюдаемая письменная традиция подтверждает гипотезу о книжном происхождении пословицы на волка помолвка. С другой стороны, активное варьирование, зафиксированное в источниках, свидетельствует, по меньшей мере, о широком освоении данного фразеологизма в русской народной культуре. Непосредственный книжный источник для пословицы волк легок на помине нами не обнаружен, хотя известны иноязычные фразеологизмы с аналогичными образами. Ср. в польском языке: «O wilku mowa a wilk tuż (podług bajki Ezopa)» [12, c. 137], тот же образ в латинской пословице lupus in fabula, используемой у Теренция [9]. Однако и в случае с этой пословицей широкое варьирование в русском языке позволяет предположить исконно русское происхождение символического образа, ср.: волк легок на помине / помяни (помянули) волка, а волк тут (а он и тут; а волк из колка) / про волка речь (промолвка), а он (волк) навстречь (и в хату); ср. серб. ми о вуку, а вук на врата. Древнерусский облик пословицы можно гипотетически восстановить с учетом лексических замен устаревших компонентов и ритмической организации народно-поэтической речи: *про вълка гълка, а вълкъ из колька (др.-рус. гълка 'шум', ст.-рус. колъ$\kappa ъ$ 'перелесок'). Не вызывает сомнений типологическая универсальность этого образа ('назовешь - появится'), в котором волк, видимо, является субституцией черта, поскольку «на имя черта накладывалось табу» [19, т. 5, с. 519]. Также существует параллель к поговорке на волка помолвка, в которой волк заменен чертом: на черта только слава, а монах поросенка съел [9].

К ядру четвертого сектора семантического поля относятся следующие фразеологизмы: 1) волком смотреть (глядеть), варианты: смотрит как волк на тебя (на теленка), ср. укр. дивитися вовком, польск. wilkiem patrzeć (культурная значимость волк 'злой, неприятный, страшный'); 2) волку зима за обычай, парафраза не первая зима волку зимовать (культурная значимость волк 'привычна тяжелая жизнь'); 3 ) хоть волков морозь (то же); 4) (хоть Лазаря (Лазарем) пой), хоть волком вой (выть) (культурная значимость волк 'крайняя степень нужды'); 5) у мужика кафтан (мужик хоть и) сер, да ум у него не волк (черт) съел (культурная значимость волк 'абсолютный хищник, 
вредитель'); 6) одна была у волка пгосенка и ту переняли (собака переняла) (культурная значимость волк 'скучная жизнь'); 7) что у волка в зубахъ, то Георгій (Егорий) даль (послал) (культурная значимость волк 'закономерность добычи хищника'); 8) волка ноги кормят (культурная значимость волк 'активная деятельность для обеспечения жизни'). В центр четвертого сектора семантического поля входят 24 фразеологические единицы, и минимум в трех случаях можно говорить о древности и вероятной архетипичности фразеологизмов, так как известны их древнерусские и иноязычные параллели. Ср.: 1) голоден как волк (как собака), ср. серб. гладан као вук, польск. głodny, żarłoczny, jak wilk (культурная значимость волк 'эталон голодного существа'); 2) рысккать волком, ср. Всеславъ ... влькомъ рыскаше в «Слове о полку Игореве» и в том же произведении вълкъмь скочити (культурная значимость волк 'резкое, быстрое движение, отсутствие покоя'); 3 ) волк и каждый год линяет, а все сер бывает (а обычай не меняет), ср. серб. вук длаку мена, а ћуд никада, латин. lupus pilum mutat, non mentem [18, с. 137] (культурная значимость волк 'неизменность (плохого) нрава'). В последнем примере у русского и иноязычных фразеологических единиц совпадает лишь образная основа, но не структура. Исконный характер русской пословицы в данном случае подтверждается употреблением устойчивого эпитета сер. Ср. примеры пословиц с этим эпитетом: не за то волка бьют, что сер; что серо, то и волк; не всё, что серо, волк [16]; всего в указанном источнике - десять фразеологических единиц с прилагательным сер(biü). Древность эпитета подтверждается контекстом из «Слова о полку Игореве»: сами скачють, акы стьрыи влъции въ поль. Многообразие и древность примеров свидетельствуют, что прилагательное серый может считаться символом всех совокупных качеств волка.

В результате обобщения символических признаков, выделенных при анализе четырех секторов семантического фразеологического поля, можно определить символический образ волка: это неизменный (предопределенный, вечный) враг человека, обитатель иного (потустороннего, дикого, опасного, безрадостного) мира, всегда готовый вторгнуться в человеческий мир за своей добычей, потому что таков установленный порядок жизни; эталонный хищник, существо злое и жестокое, однако свободное и решительное. Таким образом, символический образ волка обладает чертами амбивалентности. Анализ фразеологических единиц с компонентом волк показывает, что при описании культурной значимости слова в диахроническом аспекте необходимо учитывать степень прецедентности фразеологических единиц. На прецедентность фразеологизмов для русской языковой культуры может указывать их общеславянское происхождение, достаточная распространенность, фиксация в различных источниках и широкое варьирование.

Как показал анализ библейских фразеологизмов, христианские коннотации для лексемы волкъ более определенны. Волки как символ абсолютного зла противопоставлены овцам как символу абсолютного добра: это противопоставление поддерживается в христианской культуре глубокой символикой образа агнца. Волк как символ зла соответствует в целом образам русской и славянской фразеологии, однако выявленная на общем фразеологическом материале культурная значимость слова волк оказывается более сложной и неоднозначной. Анализ сектора I показал, что в славянской языческой культуре овца не может являться активным деятелем, в отличие от новозаветной культуры. В славянских пословицах овцы оказываются объектом действия для волка или пастуха, которые в этом смысле не только противопоставляются, но и соотносятся. Волк - это «злой» пастух, а пастух - это иногда «законный волк», т. е. хищник, поедающий овец.

Помимо примеров, приведенных выше, особый интерес представляет в ряду вариантов пословица на волка помолвка, а овеи тянет Егорка. Имя Егорка в такой пословице выступает как замена более частого варианта пастух. В то же время Егорка - это Егорий, т. е. Георгий, ср. выше что у волка в зубахъ, то Егорий даль. В последней пословице подразумевается день святого Георгия (весеннего), т. е. 23 апреля, когда у славян, в частности у восточных, было принято первый раз в году выгонять скот в поля [19, т. 5, с. 601]. Юрьев день - это общеславянский скотоводческий праздник, который, разумеется, имеет дохристианские, языческие корни. Соответственно, его посвящение христианскому святому не могло быть исконным - мы поддерживаем гипотезу, что в процессе христианизации св. Георгий получал функции Ярилы $[19$, т. 5, с. 637], а само языческое имя было вытеснено «созвучным [...] именем христианского святого Юрия-Георгия-Егория» [20, с. 181]: такое вытеснение поддерживалось народным восточнославянским произношением греческого имени [ $\gamma^{\prime}$ ӱр' $\gamma^{\prime}$ и]. В Юрьев день, в день первого выгона скота, выпекались соответствующие фигурки животных [21, с. 39]. В. Я. Пропп не считает их жертвенными, однако более широкий культурный материал позволяет оспорить его мнение: у славян было распространено в этот день ритуальное поедание жертвенного животного (ягненка) $[19$, т. 5 , с. 602], следовательно, фигурка из тестасубституция реальной жертвы. В Юрьев день у многих славян основными участниками или бенефициантами праздника становились пастухи [19, т. 5, c. 603]; вместе с тем похищение волком овец может восприниматься как сакральная жертва, которую 
назначает св. Георгий, «волчий пастух» [19, т. 1, c. 413]; в Юрьев день могли относить в поле ритуальную еду, предназначенную для волка [22, с. 193]. Соотнесение приведенных данных с ключевыми пословицами позволяет восстановить праславянскую культурную значимость слова вълкъ через реконструкцию древнейшего ритуального смысла Юрьева дня. В этот праздник должна приноситься в жертву овца / ягненок, которую поедает пастух / волчий пастух Ярило / сам волк (на волка помолвка, а овец тянет Егорка). Таким образом, волк оказывается воплощением Ярилы, божества весеннего плодородия, которому приносится в жертву овца в первый день выгона скота (что у волка в зубах, то Егорий дал).

Праславянская культурная значимость слова въл$\kappa ъ$ амбивалентна в соответствии со спецификой мифологического символа - 'священный пожиратель скота, божество плодовитости (домашних) животных'. Понятно, что указанный скотоводческий ритуал восходит к дославянской (видимо, общеевразийской) древности, поэтому общеславянский фонд паремий впоследствии, при взаимодействии с книжной культурой, успешно включал в себя аналогичные античные сюжеты (см. выше басню Эзопа), которые в конечном счете восходят к той же самой культурной значимости. С принятием христианства образ волка в значительной степени утратил свою амбивалентность и усилил негативную коннотацию, что было обусловлено в том числе и отвержением традиционной языческой символики в условиях распространения новых культурных ценностей. Таким образом, анализ фразеологических единиц позволяет проследить историческую изменчивость культурной значимости слова волк от праславянской эпохи до современности.

\section{ЛИТЕРАТУРА}

1. Алексеев A. В. Семиотические категории языка и культуры при диахроническом анализе лексики : монография. М. : МГПУ, 2013. 164 с.

2. Телия В. Н. Русская фразеология : семантический, прагматический и лингвокультурологический аспекты. М. : Языки рус. культуры, 1996. 284 с.

3. Фразеологический словарь русского языка/ Л. А. Воинова [и др.]. М. : Советская Энциклопедия, 1968. 543 c.

4. Фразеологический словарь современного русского литературного языка : в 2 т. / А. Н. Тихонов, А. Г. Ломов, А. В. Королькова ; под ред. А. Н. Тихонова. М. : Флинта: Наука, 2004. Т. 1.832 с.

5. Бирих А. К., Мокиенко В. М., Степанова Л. И. Словарь русской фразеологии. Историко-этимологический справочник. СПб. : Фолио-Пресс, 1998. 704 с.

6. Жуков В. П. Словарь русских пословиц и поговорок. М. : Русский язык, 1991. 534 с.

7. Национальный корпус русского языка. URL: http:// www.ruscorpora.ru/search-old rus.htm

8. Даль В. И. Толковый словарь живого великорусского языка. М. : Типографія Т. Рисъ, 1866. Т. 1. 627 с.

9. Михельсон А. Д. Большой толково-фразеологический словарь русского языка Михельсона. М. : Си ЭТС: Бука, 2008. CD-ROM.

10. Словарь древнерусского языка (XI-XIV вв.) : в 10 т. М. : Русский язык, 1989. Т. 2. 494 с.

11. Словарь русского языка XVIII века. Ленинград : Наука, 1988. Вып. 4. 256 с.

12. Arct M. Słownik frazeologiczny. Warszawa : Wydawnictwo M. : Arcta, 1928. 182 c.

13. Манускрипт. Древние славянские памятники. URL: http://mns.udsu.ru

14. Миленковић T. Идиоми у српском језику. Алексинац : Атеље 63, 2006. 267 с.

15. Мокиенко В. М., Никитина Т. Г. Большой словарь русских поговорок. М. : ОЛМА Медиа Групп, 2007. $784 \mathrm{c}$.

16. Уваров Н. В. Энциклопедия народной мудрости. М. : Инфра-Инженерия, 2009. 583 с.

17. Симони П. Старинные сборники русскихъ пословицъ, поговорокъ, загадокъ и проч. XVII-XIX стольтій. СПб. : Тип. Имп. Академіи Наукъ, 1899. 216 с.

18. Лазарева М. Н. Нравственный потенциал зооморфной метафоры в латинских крылатых выражениях, пословицах и поговорках // Вестник Нижегор. ун-та им. Н. И. Лобачевского. Филология. 2012. № 1 (2). С. $135-$ 138.

19. Славянские древности : этнолингвистический словарь : в 5 т. / под ред. Н. И. Толстого. М. : Международные отношения, 1995-2012. Т. 1. 575 с. Т. 5.736 с.

20. Иванов B. B., Топоров В. Н. Исследования в области славянских древностей. Лексические и фразеологические вопросы реконструкции текстов. М. : Наука, 1974. 342 c.

21. Пропn В. Я. Русские аграрные праздники (опыт историко-этнографического исследования). СПб. : Терра-Азбука, 1995. $176 \mathrm{c.}$

22. Левкиевская E. E. Славянский оберег. Семантика и структура. М. : Индрик, 2002. 336 с.

\section{REFERENCES}

1. Alekseev A. V. Semioticheskie kategorii yazyka $i$ kul'tury pri diahronicheskom analize leksiki (monografiya) [Semiotic categories of language and culture in the diachronic analysis of vocabulary (monograph)]. Moskva: MGPU, 2013. 164 p.

2. Teliya V. N. Russkaya frazeologiya: Semanticheskij, pragmaticheskij i lingvokul turologicheskij aspekty [Russian phraseology: Semantic, pragmatic and linguoculturological aspects]. Moskva: SHk. "Yazyki rus. kul'tury", 1996. 284 p.

3. Frazeologicheskij slovar' russkogo yazyka [Phraseological dictionary of the Russian language]. Moskva: Sovetskaya Entsiklopediya, 1968. 543 p.

4. Frazeologicheskij slovar' sovremennogo russkogo literaturnogo yazyka [Phraseological dictionary of modern 
Russian literary language]. In 2 v. Moskva: Flinta: Nauka, 2004. V. 1. 832 p.

5. Birih A. K., Mokienko V. M., Stepanova L. I. Slovar russkoj frazeologii. Istoriko-etimologicheskij spravochnik [Dictionary of Russian phraseology. Historical and etymological reference]. Sankt-Peterburg: Folio-Press, 1998. $704 \mathrm{p}$.

6. Zhukov V. P. Slovar' russkih poslovic i pogovorok [Dictionary of Russian Proverbs and sayings]. Moskva: Russkij yazyk, 1991. 534 p.

7. Natsional'nyj korpus russkogo yazyka [Russian National Corpus]. Available at: http://www.ruscorpora.ru/ search-old rus.htm

8. Dal' V. I. Tolkovyj slovar' zhivogo velikorusskogo yazyka [Explanatory dictionary of the living great Russian language]. Moskva: Tipografiya T. Ris": 1866. V. 1. 627 p.

9. Mihel'son A. D. Bol'shoj tolkovo-frazeologicheskij slovar' russkogo yazyka Mihel'sona [Large explanatory and phraseological dictionary of the Russian language Michelson]. Moskva: Si ETS: Buka, 2008. CD-ROM.

10. Slovar'drevnerusskogo yazyka (XI-XIV vv.) [Dictionary of the old Russian language (XI-XIV centuries)]: In 10 v. Moskva: Russkij yazyk, 1989. V. 2. 494 p.

11. Slovar' russkogo yazyka XVIII veka [Dictionary of the Russian language of the XVIII century]. Leningrad: Nauka, 1988. V. 4. 256 p.

12. Arct M. Słownik frazeologiczny [Phraseological dictionary]. Warszawa: Wydawnictwo M. Arcta, 1928. $182 \mathrm{p}$.

13. Manuskript. Drevnie slavyanskie pamyatniki [Manuscript. Ancient Slavic monuments]. Available at: http:// mns.udsu.ru

14. Milenkoviћ T. Idiomi u srpskom jeziku [Idioms in Serbian]. Aleksinac: Ateље 63, 2006. 267 p.

Московский городской педагогический университет

Алексеев А. В., кандидат филологических наук, доиент кафедры русского языка и методики преподавания филологических дисииплин

E-mail: avalekseev74@yandex.ru

Поступила в редакцию 17 октября 2019 г.

Принята к публикачии 27 декабря 2019 г.

\section{Для циитирования:}

Алексеев A. В. Культурная значимость слова волк по материалам фразеологии (диахронический аспект) // Вестник Воронежского государственного университета. Серия: Лингвистика и межкультурная коммуникация. 2020. № 1. C. 112-119. DOI: https://doi.org/10.17308/ lic. $2020.1 / 2739$
15. Mokienko V. M., Nikitina T. G. Bol'shoj slovar' russkih pogovorok [Large dictionary of Russian sayings]. Moskva: OLMA Media Grupp, 2007. 784 p.

16. Uvarov N. V. Enciklopediya narodnoj mudrosti [Encyclopedia of folk wisdom]. Moskva: Infra-Inzheneriya, 2009. 583 p.

17. Simoni P. Starinnye sborniki russkih poslovic, pogovorok, zagadok $i$ proch. XVII-XIX stoletij [Ancient collections of Russian Proverbs, sayings, riddles, etc. The XVII-XIX centuries]. Sankt-Peterburg: Tip. Imp. Akademii Nauk, 1899. 216 p.

18. Lazareva M. N. Nravstvennyj potencial zoomorfonoj metafory v latinskih krylatyh vyrazheniyah, poslovicah i pogovorkah [Moral potential of zoomorphic metaphor in Latin winged expressions, Proverbs and sayings]. Vestnik Nizhegorodskogo universiteta im. N. I. Lobachevskogo. Filologiya. Nizhnij Novgorod: NNGU, 2012. № 1(2). Pp. 135-138.

19. Slavyanskie drevnosti: Etnolingvisticheskij slovar' v 5-ti t. [Slavic antiquities: an Ethnolinguistic dictionary in 5 vols.]. Ed. by N. I. Tolstoj. Moskva: Mezhdunarodnye otnosheniya, 1995-2012. V.1. 575 p. V. 5.736 p.

20. Ivanov V. V., Toporov V. N. Issledovaniya v oblasti slavyanskih drevnostej. Leksicheskie i frazeologicheskie voprosy rekonstrukcii tekstov [Research in the field of Slavic antiquities. Lexical and phraseological questions of the reconstruction of texts]. Moskva: Nauka, 1974. 342 p.

21. Propp V. YA. Russkie agrarnye prazdniki: (Opyt istoriko-etnograficheskogo issledovaniya) [Russian agrarian holidays: (Experience of historical and ethnographic research)]. Sankt-Peterburg: Terra - Azbuka, 1995. 176 p.

22. Levkievskaya E. E. Slavyanskij obereg. Semantika $i$ struktura [Slavic amulet. Semantics and structure]. Moskva: Indrik, 2002. 336 p.

Moscow City Pedagogical University

Alekseev A. V., Candidate of Philology, Associate Professor of the Russian Language and Methods of Teaching Philological Disciplines Department

E-mail: avalekseev74@yandex.ru

Received: 17 October 2019

Accepted: 27 December 2019

\section{For citation:}

Alekseev $A$. $V$. The cultural value of the word volk (wolf) based on the materials of phraseology (diachronic aspect). Proceedings of Voronezh State University. Series: Linguistics and Intercultural Communication. 2020. No. 1. Pp. 112-119. DOI: https://doi.org/10.17308/lic.2020.1/2739 